\title{
«ВОЛЫНСКАЯ ПРОГРАММА» Г. ЮЗЕВСКОГО: СУЩНОСТЬ И ПРОБЛЕМЫ РЕАЛИЗАЦИИ (1928 - 1938 гг.)
}

\begin{abstract}
Аннотация: Предмет исследования - «вольнская программа» Г. Юзевского как попьтка комплексной трансформации соцально-политического ландшафта в Вольнском воеводстве в условиях социального и политического антагонизма в данном регионе, носивщего этническую окраску. «Вольнский эксперимент», предпринятый Г. Юзевским на основе «вольнской программы», протекал в условиях нарастания авторитаристских тенденций в политической системе Второй Речи Посполитой, что, в конечном счете, свело на нет предпринятые воеводой усилия по реализации «вольнской программы». также в статье затронут такой существенный аспект, как влияние «волынской программы» на региональный политический прочесс Вольнского воеводства и отражение в ней общегосударственного политического процесса, происходившего во Второй Речи Посполитой во второй половине межвоенного периода. В исследовании использованы общенаучные методы -логический, исторический, системный, а также специиально-научные методы - институцฺиональный, бихевиористский, функциональный. Новизна исследования заключается в том, что рассматриваемая в нем тема «Вольнской программы» Г. Юзевского и не имеет аналогов в современной российской политической науке.Основные выводыл: «Вольнская программа»-очень интересный пример концептуальной основы комплексного конструирования социально-политического пространства в условиях полиэтничного региона, в котором численное больиинство населения испьтьвает правовую, политическую, социиальную и культурную дискриминациию со стороны титульного, исходя из государственной принадлежности рассматриваемого региона, меньиинства населения.
\end{abstract}

Abstract: The object of studies is the "Volyn Program" G. Yuzevsky as an attempt of the complex transformation of social and political landscape in the Volyn province in the conditions of social and political antagonism of ethnical nature in this region. The "Volyn experiment of G.Yuzevsky based upon the "Volyn Program" took place in the conditions of growing authoritarian tendencies in the political system of the 2nd Rzeczpospolita Polska, which finally destroyed efforts of the military governor (voivod) for the implementation of the "Volyn Program". The article also concerns a significant aspect of influence of the "Volyn Program" upon the regional political aspect in the Volyn province, as a reflection of the ongoing general public political processes in the 2nd Rzeczpospolita Polska in the second half of the period between the wars. The research involved general scientific methods, such as logical, historical, systemic and special scientific methods, such as institutional, behaviorist, functional. The novelty of the study is due to the fact that the topic of "Volyn Program of G. Yuzevsky has no analogues in the modern Russian political science. The main conclusions are as follows. The "Volyn Program" is an interesting example of the conceptual basis for the construction of social and political area in the conditions of poly-ethnic region, where the majority of people are being subject to legal, political, social and cultural discrimination on the part of title nation minority from the state of which the province is the part.

Ключевые слова: Вольнское Украинское Объединение, политический прочесс, Вторая Речь Посполитая, «Вольнский эксперимент», «Вольнская программа», Вольнское воеводство, Г. Юзевский, «сокальский кордон», польско-украинское сближение, государственная интеграция.

Keywords: Volyn Ukrainian Union, political process, 2nd Rzeczpospolita Polska, Volyn Experiment, Volyn Program, Volyn province, G. Yuzevsky “Sokalsky Kordon”, Polish-Ukrainian association, public integration.

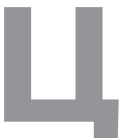

ель настоящей статьи - анализ «волынской программы» Г. Юзевского как попытки комплексной трансформации соцально-политиче-

\footnotetext{
${ }^{1}$ Польский политический деятель, Министр внутренних дел Польши (1929-1930; 1930), вице-министр внутренних дел в Правительстве Украинской Народной Республики, Волынский воевода (1928-1929 и 1930-1938 гг., с 1929 по
}

ского ландшафта в Волынском воеводстве в условиях социального и политического антагонизма в данном регионе, носившего этническую окраску.

1930 г. являлся министром внутренних дел Второй Речи Посполитой), один из ближайших сподвижников Ю. Пилсудского и соратник С. Петлюры, соавтор польско-украинского соглашения 1920 г. 
DOI: $10.7256 / 1811-9018.2014 .6 .12032$

При цитировании этой статьи сноска на dоі обязательна

\section{Право и политика $6(174) \cdot 2014$}

Актуальность поднятой в настоящей статье темы обусловлена тем, что «волынская программа» Г. Юзевского слабо изучена в политической науке, тогда как она представляет собой интересный пример попытки комплексного конструирования политических, экономических, социальных и культурных оснований политического процесса в условиях, когда титульная нация значительно уступает по численности формальным «национальным меньшинствам»², которых в границах постверсальской Польши насчитывалось $33^{3}$, при этом значительно превосходя их в социальном статусе и возможностях социальной мобильности. При этом, среди восточных воеводств Второй Речи Посполитой Волынское 4 выделялось спецификой политических, экономических, национальных и межконфессиональных отношений, что непосредственно отражалось на протекавшем в нем политическом процессе.

Период воеводства Г. Юзевского на Волыни, в целом, пользуется вниманием польских и украинских

\footnotetext{
2 По данным переписи 1931 г., население Волынского воеводства возросло, по сравнению с 1921 г., на 32,73\%, и достигло 2085,6 тыс. чел. (по данным С. Макарчука - 2181 тыс. чел. // Макарчук C. А. Этносоциальное развитие и национальные отношения на западноукраинских землях при империализме: автореф. дисс. ... канд. ист. наук. К., 1984. С. 33), превысив, таким образом, уровень 1910/11 г. Из этого числа украиноязычных жителей насчитывалось 1426,9 тыс. чел. (по подсчетам С. Макарчука - 1509 тыс. чел. // Там же), поляков 346,6 тыс., евреев 205,5 тыс., чехов 31 тыс., русских 23,3 тыс. чел. (Tomaszewski J. The national structure of the working class in the south-eastern part of Poland (1918 - 1939) // Actae Poloniae historica. 1968. № 19. Р. 97). Доля поляков в населении Волынского воеводства в 1936 г. составляла 16,5\%, с 1921 г. их удельный вес увеличился на $5 \%$ (Шваб $А$. $Г$. Еміграція 3 Волині 1921-1939 рр.: автореф. дис. ... канд. іст. наук. Чернівці, 1996. С. 13; Чубинськи А. Борьба Коммунистической партии Польши за справедливое решение национального вопроса в 1918-1939 гг. // Великий Октябрь и национальный вопрос. Ереван, 1977. С. 291) - преимущественно, в городском населении. Если по переписи 1921 г. в городах региона поляки составляли, в целом, $16 \%$, украинцы - $22 \%$, а евреи - $57 \%$ населения, то в 1931 г. доля поляков в них выросла до 28\%, украинцев - уменьшилась до $16 \%$, а евреев - до 49\% (Шваб А. Г. Національна політика II Речі Посполитої та еміграційні процеси на західно-українських землях // Україна: культурна спадщина, національна свідомість, державність. Львів, 2008. Вип. 17. С. 149).

${ }^{3}$ Не считая, собственно, поляков. (Крамар Ю. В. Українськопольські взаємовідносини на Волині у міжвоєнний період (за документами Державного архіву Волинської області) // «Архіви України». 2013. № 3. С. 116).

${ }^{4}$ Образовано 19 февраля 1921 г. С 1921 г. в административном отношении польская часть Волыни делилась на 11, с 1930 г., за счет включения Сарненского повета, - 12 поветов.
}

ученых ${ }^{5}$, но, как правило, - историков ${ }^{6}$. При этом, если одни ${ }^{7}$ основное внимание обращают на него сквозь призму политики Г. Юзевского как представителя польской власти в регионе и намного меньше освещают активное в тот период украинское политическое движение в воеводстве - в частности, ВУО и его лидеров, то другие ${ }^{8}$, наоборот, основное внимание уделяют

\section{${ }^{5}$ Хотя в значительно меньшей степени, чем период УНР и «Во- лынская резня» 1943 г. \\ ${ }^{6}$ Главный массив документов для изучения указанной проблемы} сосредоточен в материалах фонда 46 («Волинське воєводське управління») Государственного архива Волынской области. Это, прежде всего, циркуляры, приказы, распоряжения воеводского правления, протоколы заседаний руководителей органов исполнительной власти и инстанций воеводства, протоколы съездов старост, заседаний воеводского совета и органов местного самоуправления. Интересные факты содержат годовые отчеты воеводы о политическом и экономическом положении в воеводстве. Данные материалы дополняются отчетами воеводской и поветовых команд державной полиции об общественно-политической ситуации в отдельных уездах воеводства. Определенные трудности в работе с этими документами обусловлены тем, что документы воеводского правления сохранились не полностью, а потому порой являются фрагментарными. Ценные сведения об украинском национальном движении Волыни, о деятельности украинских политических партий и общественных организаций на территории Волынского воеводства содержат материалы фондов 1 («Волинська воєводська команда державної поліції»), 36 («Луцьке повітове староство»), 45 («Луцька повітова команда державної поліції»), 58 («Цивільне управління земель Волинських і фронту Подільського»), 60 («Українська парламентарна репрезентація на Волині») и 198 («Луцька окружна управа Волинського українського об’єднання»).

${ }^{7}$ Kęsik J. (Struktura narodowościowa województwa wołyńskiego w latach 1931-1939 // Przemiany narodowościowe na Kresach Wschodnich II Rzeczypospolitej 1931-1948, red. St. Ciesielskiego. Toruń, 2004; Zaufany Komendanta. Biografia polityczna J. H. Józewskiego. 1892-1981. Wrocław, 1995, и др. ); Medrzecki W. Województwo Wołyńskie 1921-1939: elementy przemian cywilizacjnych, społecznych I politycznych. Wrocław; Kraków, 1988; Potocki R. Polityka państwa polskiego wobec zagadnienia ukraińskiego w latach. 1930-1939. Lublin, 2003; Chojnowski A. Koncepcje polityki narodowościowej rządów polskich w latach 1921-1939. Wrocław, 1979.

${ }^{8}$ М. Кучерепа (Волинське українське об'єднання (1931-1939рр.). Луцьк, 2001; Кучерепа М., Щеблюк С. Профспілковий рух на Волині у міжвоєнний період (1921-1939рр.) // Вісник Академії праці і соціальних відносин Федерації профспілок України: Науково-методичний збірник. 2009. № 3 (50).С. 118-126), Я. Цещик (Діяльність УНДО на Волині в контексті зміни політичної тактики партії (друга половина 1935 - 1939 рр.) // Актуальні проблеми вітчизняної та всесвітньої історії. Рівне, 2008. Вип.12. С. 104-111; Участь українських національних партій у парламентських виборах на Волині 1928 - 1930 рр. // Актуальні проблеми вітчизняної та всесвітньої історії. Рівне, 2008. Вип.12. С. 104-113; Боротьба українського населення за збереження національної освіти на Волині у 1930-х рр. // Історичний архів. Наукові студії. Миколаїв, 2009. Вип. 3. С.128-131; Початок діяльності Українського національно-демократичного об’єднання на Волині (1925 - 1928 рр.) // Актуальні проблеми вітчизняної та всесвітньої історії. Рівне, 2009. Вип.15. С. 128-134; Роль Української соціалістично-радикальної 
DOI: $10.7256 / 1811-9018.2014 .6 .12032$

При цитировании этой статьи сноска на dоі обязательна

История государства и права

именно им. Внимание в этих работах часто акцентируется на проблемах, способствовавших углублению конфронтации в межнациональных отношениях на Волыни в 1920-30-е гг., тогда как публикаций, освещающих попытки достичь взаимопонимания между поляками и украинцами, поиски путей сотрудничества двух народов, мало 9 . Кроме того, до сих пор практически не предпринималось попыток изучения воеводства Г. Юзевского с позиции социальных наук ${ }^{10}$, тогда как без анализа многих имевших место в тот период в регионе противоречивых социальных и политических факторов и закономерностей, их научного анализа полноценное раскрытие данной темы представляется весьма затруднительным.

Волынское воеводство являлось регионом в составе Второй Речи Посполитой, имевшим для страны большое геополитическое значение. Это проявлялось в следующих аспектах. Во-первых, оно было вторым по площади в стране $\left(35,7\right.$ км$\left.^{2}\right)$ - после Полесского $(36,7$ км²). Во-вторых, Волынь до первой трети XX в. никогда не являлась разделенным регионом ${ }^{11}$, тогда как между ней и Восточной Галицией исторически имелась социокультурная граница. Кроме того, не было историко-культурных рубежей и с располагавшимся к северу от рассматриваемого региона Полесским воеводством. В-третьих, на территории Волынского воеводства на рубеже 1910-1920-х гг. располагался один из центров украинского государствообразования, и

партії у політичному житті Волині (1926 - 1928 рр.) // Сторінки історії. К., 2009. Вип. 28. С. 136-147, и др.), Р. Давидюк (Відносини Організації українських націоналістів (ОУН) і Волинського українського об'єднання (ВУО) у 1931-1939 роках // Наук. вісн. Волин. держ. ун-та ім. Лесі Українки. Луцьк, 1999. № 5: Іст. науки. С. 107-111; Розмежування Західної Волині та Східної Галичини як складова «волинського експерименту» Генрика Юзевського // Сучасна українська держава: історичні імперативи становлення, тенденції та проблеми розвитку: збірник / редкол.: Ю. А. Левенець та ін. К., 2006. С. 498-509; Трансформація українського національно-демократичного руху у Волинському воєводстві (30-і pp. ХХ ст.) // Слов'янський вісник. Вип. 14. Рівне, 2012. С. 28 - 31 и др.); Ю. Крамар (Участь українських політичних партій у парламентських виборах 1930 року на Волині // Наук. вісн. Волин. нац. ун-ту ім. Лесі Українки. Рівне, 2007. Вип. 1: Іст. науки. С. 198 - 203, и др.). Особо отметим монографию и сборник документов по политическим партиям межвоенной Волыни (Кучерепа M., Цецик Я. Українські національні партії на Волині (1921 - 1939 рр.). У 2 частинах. - Ч. 1: Монографія; Ч. 2: Документи і матеріали. Луцьк, 2011.

${ }^{9}$ Гнатюк О. Між літературою і політикою. Есеї та інтермедії. K., 2012.

${ }^{10}$ См.: Давидюк Р. П. Політичні процесі Західної Волині міжвоєнного періоду в сучасній українській історіографії // Слов'янський вісник. Збірник наукових праць. Рівне, 2010. Вип. 10. С. 51 - 57.

${ }^{11}$ Восточная часть Волыни после 1921 г. осталась в границах УССР. руководство Украинской Народной Республики имело союзнические отношения с Польшей Пилсудского, что являлось для руководства Польской Республики немаловажным фактором.

Следует отметить, что характер политического процесса определяется многими, неразрывно связанными между собой, внешними и внутренними факторами: системой экономических, социальных, правовых, социокультурных и иных отношений, политической культурой населения - ядром социокультурной среды процесса, сущностными качествами его акторов, их интересами и установками, стратегией и тактикой деятельности, ресурсами влияния. Данные факторы обеспечивают динамический компонент политического процесса - политические изменения, как постоянный переход от одного состояния общества в другое, что является универсальным свойством политических систем. Политические изменения - это преобразования институтов, норм и целей, типов деятельности людей в политике, которые существенно влияют на обновление политической системы или отдельных её элементов $^{12}$. Обозначим наиболее значимые из факторов политического процесса применительно к Волынскому воеводству первой трети XX в.

Во-первых, характер динамики регионального политического процесса в рассматриваемом регионе определялся, в значительной степени, его хозяйственно-экономической отсталостью и наличием у украинского большинства населения ряда острых социальных проблем - низкого уровня жизни и социального обеспечения, отсутствия доступа к получению образования на родном языке, социальных гарантий и т. д., а также собственной региональной политической силы с мощной идеологической базой. Важно понимать, что по уровню хозяйственного развития Волынское воеводство было одним из самых отсталых регионов Польской Республики: значительные военные разрушения, вызванные Первой мировой войной, удаленность воеводства от основных промышленных центров страны, тяжелая экономическая ситуация в самой Польше обусловили низкую инвестиционную активность государства на Волыни в первые годы ее пребывания в составе Второй Речи Посполитой. Лишь с середины 1920-х годов наметились определенные сдвиги в сторону прогресса в данной сфере. При этом,

\footnotetext{
${ }^{12}$ Шутов А. Ю. Политический процесс. М., 1994. С. 15; Категории политической науки / Авт. концепции и рук. авт. кол. А. Ю. Мельвиль. М., 2002. С. 359.
} 


\section{Право и политика $6(174) \cdot 2014$}

аграрный характер волынского общества ${ }^{13}$ предопределил относительно неширокий уровень активного сознательного включения населения в политический процесс $^{14}$ и, соответственно, патриархально-подданнический тип политической культуры ${ }^{15}$. Складывалась типичная для «восточных кресов» ситуация, когда сознательным участником политического процесса было, главным образом, городское население, тогда как массы крестьян - как украинских, так и польских, являлись, в основном, ареной борьбы за привлечение сторонников как для пропольских, так и антипольских политических сил, а вместе с ними - соответствующих культурно-просветительских и иных общественных организаций, католических и униатских миссионеров.

Важным обстоятельством, оказывающим воздействие на политические процессы, является характер социальной структуры населения. В этом плане оно дифференцировалась практически аналогично национальной структуре. Так, поляки, составлявшие значительную часть городского населения, являлись, главным образом, чиновниками и госслужащими. Еврейское население работало в сфере торговли, ремесла. Украинцы же, как отмечалось выше, занимались земледелием. Если поляки в течение межвоенного периода проживали в городах и работали в учреждениях, связанных с функционированием государства ${ }^{16}$, то украинцы, чаще всего, жили не в самих городах, а в пригородах либо вдали от немногочисленных урбанизированных зон и занимались

\footnotetext{
${ }^{13}$ При этом, 85,8\% населения воеводства в 1931 г. составляли сельские жители (Шваб А. Г. Еміграція з Волині... С. 11), доля их среди православного населения в 1931 г. составляла 93\% населения (Kęsik J. Struktura narodowościowa... // Przemiany narodowościowe na Kresach Wschodnich II Rzeczypospolitej 1931-1948, red. St. Ciesielskiego. S. 138), 7,2\% были заняты в ремесле и частном промысле, $5,7 \%$ - в торговле, $1,9 \%$ - в социальной сфере и 1,2\% - в средствах коммуникации и на транспорте (Шваб А. Г. Соціальноекономічні процеси на Волині у міжвоєнний період // Волин. Нац. ун-т ім. Лесі Українки. Зб. навч. - методич. Мат-лів і наук. статей Іст. фак-ту. Луцьк, 2008. Вип. 14. С. 98).

${ }^{14}$ Об этом говорит такой показатель, как явка избирателей на участки. Так, на выборах в Сенат, состоявшихся 25 мая 1930 г., из 506 тыс. избирателей воеводства проголосовали 112,3 тыс. чел., в Сейм - из 227 тыс. избирателей одного Ковельского округа проголосовали 40,1 тыс. чел. (Боротьба трудящих Волині за визволення 3-під гніту панської Польщі і возз'єднання з радянською Україною: збірник документів і матеріалів. Частина II (1929 - 1939 рр.). Львів, 1965. С. $20-21)$.

${ }^{15}$ Согласно классификации М. Вебера.

${ }^{16}$ Евреи, составлявшие заметный процент населения воеводства, также проживали, как правило, в городах, фактически обеспечивая функционирование их экономики и торговли.
}

земледелием ${ }^{17}$. Прибывшие же в аграрные районы Волынского воеводства, в рамках правительственной программы аграрной колонизации, несколько тысяч военных колонистов-«осадников» из «коренной» Польши рассматривались властями как их опора в зачастую мятежной сельской глубинке. Выдвинутая под лозунгом защиты крестьянских интересов, в действительности эта программа достигала поставленной цели только в «коренной» Польше, на Волыни же её реализация формировала привилегированную и преданную власти прослойку сельских жителей, с помощью которой можно было бы разбавить пространство сплошного украинского заселения и контролировать его деятельность. В целом, Волынское воеводство занимало решающее место в данной программе: до января 1923 г. здесь было выделено для колонистов 111,7 тыс. га земель, на которых разместилось 3541 осадницкое хозяйство ${ }^{18}$. Таким образом, на этническую дифференциацию населения региона накладывалась его социальная дифференциация, что само по себе являлось обстоятельством, затруднявшим интеграционные социально-политические и культурные процессы между тремя ключевыми народами Волыни ${ }^{19}$.

Польские колонисты, переселившиеся в данный регион из «коренной» Польши, поляки, проживавшие в городах, а также украинская интеллигенция, бывшие в свое время основной движущей силой процесса государствобразования, охватившего украинские земли в конце 1910-х гг., когда Волынь являлась одним из цен-

\footnotetext{
${ }^{17}$ При этом и поляки, и украинцы были своего рода «раздражителями» для политической активности друг друга.

${ }^{18}$ Крамар Ю. В. Українсько-польські взаємовідносини... // «Архіви України». № 3/2013. С. 118.

${ }^{19}$ Серьезные проблемы имели место в сфере украинского национального образования. Конечно, польское население имело доступ в школы любого уровня. В то же время, этого нельзя сказать об украинцах: неграмотных в начале 1920 -х гг. было $44 \%$ жителей (Сборник материалов для военно-географического описания стран, сопредельных с западным фронтом. Вып. 1. Польша. - М., 1921. С. 18). В 1927 - 28 учебном году на Волыни получало образование 111843 ребенка (51,1\%) в 1185 начальных школах, а 106943 (48,9\%) - оставалось необразованными и неграмотными (Панасюк В. «Волинська політика» воєвод Г. Юзевського та А. Гавке-Новака 1928 - 1939 років: проблеми україно- та німецькомовної освіти // «Етнічна історія народів Свропи». Збірник наукових праць. К., 2004. Вип. 16. С. 126). Согласно же рапорту волынского воеводского коменданта державной полиции от 3 мая 1938 г., 100 тыс. детей (главным образом, проживавших в сельской местности украинцев) не учились в школе, при том, что наличествовало 2 тыс. безработных учителей (Боротьба трудящих Волині... Частина II. С. 364). Такое состояние было реальной угрозой на пути приобщения украинской молодежи к польской культуре.
} 
тров этого процесса, представляли собой социальную базу и, при этом, представляли собой главные субъекты общественно-политического движения в Волынском воеводстве в межвоенный период. Необходимо упомянуть и зажиточных крестьян.

Во-вторых, для волынских украинцев - как и для всего восточнославянского населения Второй Речи Посполитой, за исключением прикарпатских бойков и лемков, в межвоенный период польскими властями были искусственно созданы серьезные барьеры для участия в общественной жизни и системе общественных отношений в целом, прежде всего - барьер языковой. Все они препятствовали полноценному политическому, социально-экономическому и культурному развитию восточнославянского большинства населения воеводства, хотя о его политической самоорганизации в рассматриваемом регионе можно говорить, начиная с парламентской избирательной кампании 1922 г.

В-третьих, Западная Волынь являлась и в межвоенный период, и в наши дни продолжает оставаться регионом, расположенным на границе компактного проживания западно- и восточнославянского населения и, при этом, участком конфессионального и культурного рубежа между католической и православной цивилизациями. В периоды нахождения западной части Волыни в составе Польского государства здесь неоднократно осуществлялась агрессивная религиозная и культурная экспансия в отношении её православного населения, инспирируемая руководством Римо-Католической Церкви и, как правило, активно поддерживаемая государственной властью в Варшаве. Та исходила из установки, согласно которой польская, основанная на римо-католичестве и западноевропейской правовой традиции, культура более высокая, нежели местная аграрно-православная.

Под влиянием политики польских властей, проводившейся в течение 1919 - 1926 гг. и направленной на национальную ассимиляцию восточнославянского населения региона, к началу ${ }^{20}$ воеводства Генрика Юзевского в Волынском воеводстве стремительно развивалась фрагментарная политическая культура, фактически представлявшая собой совокупность этнолингвистических субкультур с незначительным уровнем этносоциокультурной интеграции, и ключевой задачей, стоявшей перед ним, было преодолеть данную тенденцию. Учитывая это, а также то обстоятельство, что на территории Волынского воеводства располагал-

\footnotetext{
${ }^{20}$ Следует отметить, что более лояльную политику в отношении
} украинцев проводил воевода Владислав Мех в 1926 - 1928 гг. ся значительный политический и религиозный центр украинского национального движения, вероятность конфликта польской и стремительно развивавшейся украинской культур, в том числе и политических, при дальнейшем сохранении обозначенных тенденций резко возрастала.

Выстроить концепцию «волынского эксперимента» Г. Юзевскому позволило прагматическое и многоуровневое видение проблем, имевшихся в воеводстве как с польской, так и с украинской сторон. Эксперимент касался всех сторон жизни воеводства и был так назван, во многом, потому, что воевода не исключал в будущем возможности его расширения на всю территорию «восточных кресов», кроме Галиции. Концепция была раскрыта в «волынской программе».

Суть программы заключалась в «государственной ассимиляции» и воспитании подданных Второй Речи Посполитой, которое должно было начинаться уже на стадии школьного образования. «Государственная ассимиляция» предполагала разностороннюю интеграцию разношерстного в этнополитическом и социокультурном отношениях волынского населения, формирование единого политического пространства, основанного на отлаженной системе политической коммуникации, эффективную организацию политического процесса и, в конечном счете, становление сильного региона, который мог бы стать опорой правительства Польши на востоке страны. При этом, должно было произойти взаимопроникновение не терявших своей идентичности украинской и польской культур и «насыщение украинских национальных черт польскими началами» ${ }^{21}$, и при этом - их «встраивание» в единую государственно-политическую систему Польши, что свидетельствовало о приоритетной роли политической составляющей «волынской программы» и предпочтении в ней польской стороне.

Идейно-концептуальной основой «волынской программы» было то, что она преследовала цель создать на территории воеводства своеобразный анклав польско-украинского общежития и согласия на основе Ягеллонских традиций ${ }^{22}$ и «идеологии 1920 г.» (т. е., в духе Варшавского соглашения между Петлюрой и

${ }^{21}$ Кугутяк М. В. Історія української націонал-демократії (19181929). Т. 1. К.; Івано-Франківськ, 2002. С. 400-401.

${ }^{22}$ Они восходят к «ягеллонской идее», сформированной польскими королями Ягеллонской династии (1386 - 1572 гг.) в XV в. и заключающейся в создании федеративного государства в составе Польского королевства и Великого княжества Литовского с целью осуществления далеко идущей цивилизаторской миссии Польши на востоке. 
DOI: $10.7256 / 1811-9018.2014 .6 .12032$

При цитировании этой статьи сноска на dоі обязательна

\section{Право и политика $6(174) \cdot 2014$}

Пилсудским 1920 г. $)^{23}$, для чего предполагалось привлекать украинцев, и прежде всего, деятелей бывшей УНР, к политической жизни страны путем расширения их участия в деятельности законодательных органов, органов местной администрации и самоуправления, кооперативных организаций.

Воеводству в планах воеводы предстояло также стать центром подготовки кадров украинцев, которые, при удачной международной конъюнктуре, смогли бы сыграть решающую роль в строительстве независимого государства на территории тогдашней Советской Украины, хотя его территория должна была остаться в составе Польши. Более того, Г. Юзевский утверждал, что именно Волынь должна стать «украинским Пьемонтом», основой для построения независимой Украины, играющей ту же роль, что и Пьемонт в объединении Италии ${ }^{24}$. Соответственно, воеводство рассматривалось как регион, в котором польско-украинские отношения должны выстраиваться на принципах широкого сотрудничества, условием которого воевода считал рост политической активности населения региона ${ }^{25}$. Учитывая имевшиеся в жизни украинского населения региона проблемы, достижение поставленных целей было крайне сложной задачей.

Программа Г. Юзевского во многом соответствовала мысли генерала В. Сикорского ${ }^{26}$, обнародованной еще в 1926 г. Тот, придерживаясь «федералистской» концепции, исходил из принципа, согласно которому Польша - не монолитное государство, и предлагал допустить активизацию общественных сил в различных регионах страны путем децентрализации власти

\footnotetext{
${ }^{23}$ Kesik J. Zaufany Komendanta... S. 121. Оно предполагало обязательство правительства УНР во главе с Петлюрой взамен на признание оказывать помощь полякам в борьбе с большевиками. $\mathrm{B}$ соответствии с договором, поляки обязались не признавать международных соглашений, направленных против Украины, гарантировали соблюдение национально-культурных прав украинского населения, которое оказывалось на территории польского государства. Аналогичные права поляков на территории Украины признавало правительство Петлюры.

${ }^{24}$ Всего в истории можно насчитать три идеи «украинского Пьемонта», которому географически соответствовали Восточная Галиция, Волынское воеводство и «Закарпатская Русь». Первая выдвинута украинскими национальными организациями, вторая - польской администрацией Волынского воеводства, третья - руководством Подкарпатской Руси в 1938 г.

${ }^{25}$ Chojnowski A. Koncepcje polityki narodowościowej... S. 92.

${ }^{26}$ Польский военачальник и политик, премьер-министр в 1922 - 1923 гг., военный министр в 1924 - 1925 гг., генерал брони (генерал-полковник), глава эмиграционного правительства Польши в 1939 - 1943 гг.
}

на уровне воеводских правлений и органов местного самоуправления и привлечения к работе в регионах, насколько возможно, большего числа наиболее ценных людских ресурсов вне зависимости от их национальной принадлежности. Это предполагалось делать с помощью особых региональных комитетов, состоявших из воеводы-председателя и людей, игравших существенную общественную и политическую роль в данном регионе. На основе этих принципов, в начале 1927 г. был образован Волынский региональный комитет, охватывавший правящие группы региона. Аналогичное учреждение было создано в Львове - для Восточной Галиции, включавшей 3 воеводства.

Впрочем, «украинофильство» волынского воеводы не стоит преувеличивать. Г. Юзевский был и оставался польским воеводой, прекрасно осознававшим приоритеты. Он считал, что «не может так быть, чтобы на Волыни существовало отдельное украинское национальное движение. Оно может развиваться только в рамках сожительства, в котором управляет польский элемент ${ }^{27}$ и дозволяется лишь столько украинской жизни, сколько может перенести польское организованное национальное движение» ${ }^{28}$.

«Волынская программа» была официально предложена Г. Юзевским на конференции «кресовых» ${ }^{29}$ воевод в Луцке, состоявшейся 8 декабря 1929 г. ${ }^{30}$, но её первые наброски он озвучил там же на съезде послов и сенаторов Волыни, который состоялся уже 20 августа 1928 г. Её предполагалось осуществлять по следующим направлениям: 1) повышение эффективности функционирования польской администрации с доброжелательным при этом её отношением к украинскому населению; 2) усиление значения органов местного самоуправления в общественной и хозяйственной жизни; 3) пробуждение среди украинского населения пропольских патриотических чувств посредством развития двуязычной польско-украинской школы ${ }^{31}$;

\footnotetext{
${ }^{27}$ Выделено нами - Е.Б.

${ }^{28}$ Цецик Я. П. Вплив Українського національно-демократичного об'єднання на суспільно-політичне життя Волині напередодні Другої світової війни // Науковий вісник: Одеський національний економічний університет. - Науки: економіка, політологія, історія. Одеса, 2012. № 2. С. 146.

${ }^{29}$ Волынского, Полесского, Гродненского, Виленского, Белостокского.

${ }^{30}$ См. «Протокол конференції воєвод східних воєводств Польщі» // ДАВО, ф. 46, оп. 1, спр. 544.

${ }^{31}$ Всерьез усилиться Польше, считал воевода, «можно тогда, когда гражданин Речи Посполитой непольского происхождения станет ее верным сыном, сыном своей Родины, когда энергия массы граждан непольского происхождения увеличит ее государственной
} 
4) создание условий для организации украинской интеллигенции, придерживающейся идей польскоукраинского договора 1920 г. и доброжелательной к Польше, но вместе с этим - ликвидация политических групп, вдохновляемых внешними относительно воеводства центрами (Львов, Москва); 5) убеждение волынских поляков в необходимости федеративной идеи и сотрудничества между ними и украинцами; 6) расширение культурного и хозяйственного обмена между Западной Волынью и остальными регионами Польши с целью ознакомления украинского населения с достижениями польской культуры и западной цивилизации в целом; 7) широкая инвестиционная деятельность для повышения цивилизованности региона и улучшения экономической ситуации в нем; 8) создание смешанных по национальному составу польско-украинский организаций в разных сферах общественной жизни, для чего, на взгляд воеводы, имелись весомая предпосылка - многовековой опыт бесконфликтного сосуществования украинцев и поляков ${ }^{32}$. При этом, в первую очередь предполагалось создать общественные организации, и лишь затем - политические.

Программа была рассчитана на формирование среди местного украинского населения такого уровня лояльности к Польскому государству, при котором оно бы не захотело отделиться от Польши даже после восстановления самостоятельности Украины в её исторических центральных областях, находившихся тогда в границах $\mathrm{УCCP}^{33}$.

энергию, творческую силу, которая освобождает из жизни ценные начала. Ее слабость, которая приведет к поражению, определит ситуация, когда гражданин непольского происхождения станет врагом Польши и всего польского, когда энергия граждан непольского происхождения будет направлена против нее и станет фактором деструкции, постоянной борьбы». Отчет за 1936 г. Цит. по: http:// uadocs.exdat.com/docs/index-170605.html?page=14

32 В своих воспоминаниях воевода писал: «Возникает мысль: а получилось ли бы создать смешанные общественные организации в случае замены украинцев людьми другой национальности, например, русскими или немцами? <...> Не представляю себе смешанной польско-русской или польско-немецкой общественной организации. Можно понять российские организации полякам или польские - россиянам. Однако, это не будут смешанные общественные организации в понимаемом нами смысле. Не представляю себе такой ситуации и с немцами. Это указывает на особую связь между тем, что польское, и тем - что украинское, на польское и украинское «я», на польско-украинское «мы» (Генрик Юзевський. Замість щоденника // «Роде наш красний...» Волинь у долях краян і людських документах. Т. 2. Луцьк, 1996. С. 208).

33 Реальное положение дел в воеводстве было таким, что к последней трети 1920-х гг. его украинское население очень заметно симпатизировало своим братьям в УССР и зачастую просто ненавидело Польское Государство.
Главным условием реализации «волынского эксперимента» была ликвидация влияния на политический процесс в Волынском воеводстве общественно-политических, экономических и культурных организаций из Восточной Галиции ${ }^{34}$ (прежде всего, УНДО и ОУН) и Советского Союза ${ }^{35}$ (КПЗУ). Г. Юзевский считал, что украинцы Волыни совершенно отличаются от украинцев галицийских ${ }^{36}$. Действительно, в социокультурном плане Волынь значительно ближе к Полесью, Новогрудчине и Виленщине ${ }^{37}$, чем к Восточной Галиции. И это облегчало задачу ограничения влияния со стороны украинского общественно-политического движения Восточной Галиции и, при этом, осложняло задачу выстраивания заслона со стороны восточной, в то время советской, части Волыни, которая никогда до 1921 г. не была отделена от западной. Неудивительно, что Польское Правительство решало данную проблему при помощи силового подхода, создав 50-километровую милитаризированную зону вдоль всей советско-польской границы, значительная часть которой совпадала с «волынско-волынской» границей, и передачи управления в ней КОПу - Корпусу пограничной охраны, руководство которого, придерживаясь противоположного взгляда на решение украинского вопроса, ориентированного преимущественно в сторону репрессивных действий, хозяйничало в регионе наряду с воеводской администрацией, фактически вытеснив её из приграничной полосы.

Рассмотрим реализацию «волынской программы» Г. Юзевского сквозь призму основных декларированных в ней направлений.

После назначения на Волынь первоочередной задачей воеводы было формирование надежной команды и кадровой основы для проведения «волынского эксперимента». Неудивительно, что, прежде всех, к реализации программы волынского воеводы присоединились представители петлюровских структур, которые были особенно связаны с воеводой. Бывшие деятели УНР -

\footnotetext{
${ }^{34}$ По мнению воеводы, украинцев из Восточной Галиции в коем случае нельзя отождествлять с украинцами из «польской Волыни», причем не только из-за экономических и культурных различий обеих территорий, а, в первую очередь, в связи с их разной политической ориентацией. (Крамар Ю. В. Українсько-польські взаємовідносини... // «Архіви України». № 3/2013. С. 121)

${ }^{35}$ KęsikJ. Struktura narodowościowa... // Przemiany narodowościowe... S. 149.

36 Достаточно вспомнить о большой роли в формировании этих различий «Сокальского кордона».

${ }^{37}$ Sawicka J. Złota wołyńska struna. O Łobodowskim w tygodniku «Wołyń» // Kresy. 1991. Nr. 16. S. 57.
} 
DOI: $10.7256 / 1811-9018.2014 .6 .12032$

При цитировании этой статьи сноска на доі обязательна

\section{Право и политика $6(174) \cdot 2014$}

«выходцы из 1920 г.» ${ }^{38}$, как их называл Г. Юзевский, были носителями украинской национальной идеи, генератором политической, культурно-просветительской, религиозной, кооперативной жизни на Волыни. Воевода опирался в своей работе и на образованную к парламентским выборам 1930 г. совместную польскоукраинскую парламентскую репрезентацию Волыни во главе с поляком И. Пулавским и его заместителем украинцем П. Певним. Последний одновременно был лидером Украинской парламентской репрезентации Волыни (УПРВ) ${ }^{39}$. Вместе с тем, как опытный политик, Г. Юзевский понимал, что для реализации «волынской программы» нужны новые кадры, не обремененные противоречивым наследием прошлого. Их подготовку осуществлял Кременецкий лицей: ежегодно в нем устраивались два 4-месячных курса для молодежи (мужской и женский), которые подготавливали сельских общественных деятелей к ведению культурнопросветительной работы и распространения идей польско-украинского сотрудничества ${ }^{40}$. До 1939 г. число подобных заведений достигло трех ${ }^{41}$. Печатным органом политики польско-украинского сотрудничества стал переведенный из Варшавы в Луцк еженедельник «Украинская нива».

Касательно окружения Г. Юзевского в резолюции Компартии Западной Украины, принятой на её конференции еще до назначения Г. Юзевского воеводой, в 1927 г., отмечалось: «Правительство Пилсудского окружило петлюровщину как моральной, так и материальной опекой. Оно [...] назначает их на государственные и частные должности в основном на Волыни, где, между прочим, осел известный петлюровский деятель Ковалевский (председатель Украинского бан-

${ }^{38}$ Крамар Ю. В. Участь українських політичних сил Волині, Холмщини та Підляшшя у парламентських виборах 1922 р. // Наук. вісн. Волин. нац. ун-ту ім. Лесі Українки. Луцьк, 2009. Вип. 13: Іст. науки. С. 200.

${ }^{39}$ Она насчитывала 6 послов и 2 сенаторов (Давидюк Р. Українськопольські організації як прояв міграцйної політики влади на Волині у міжвоєнний перод // Актуальні проблеми вітчизняної та всесвітньої історії: Зб. наук. праць. Наук. зап. Рівненського держ. гум. ун-ту. Рівне, 2009. Вип. 17. Эл. версия: http://archive. nbuv.gov.ua/portal/soc_gum/apvvi/2009_17/davyduk.pdf). В состав этой группы вошли послы П. Певний, М. Тележинський, М. Буря, С. Скрипник, В. Серафимович, Е. Богуславський и сенаторы М. Маслов и И. Гловацкий. Все они были будущими деятелями ВУО.

${ }^{40}$ Сивіцький М. Історія польсько-українських конфліктів. Т. 1// Эл. версия: http://uadocs.exdat.com/docs/index-170605.html?page=12

${ }^{41}$ Помимо этого, в 1935 г. был открыт второй народный университет в Ружине вблизи Ковеля под руководством известного общественного деятеля К. Банаха. Третий НУ, открытый в 1939 г. в Малинске Костопольского повета, не успел выпустить слушателей. ка в Луцке). Правительство Пилсудского организует на Волыни украинские петлюровские кооперативы, выдает им субсидии. <..> Оно финансирует петлюровское издательство «Украинская нива» (в Варшаве) и при помощи своих административных органов распространяет его издания на Волыни» ${ }^{42}$. Такая реакция коммунистов неудивительна: на страницах печати, в своих выступлениях УНРовцы резко критиковали советскую действительность, особенно политику коллективизации, которая привела к Голодомору 19321933 гг. в УССР, атеизацию и идеологизацию советских украинцев, оттолкнувших от симпатий к советскому строю многих украинцев воеводства.

Если кадры для интеграционной политики с украинской стороны найти удалось, то с поляками дело обстояло значительно сложнее. Так, польские помещики Волыни - одна из самых активных в политическом отношении сил региона, владевшие значительным количеством земли, были разочарованы проводимой правительством аграрной политикой ${ }^{43}$, и когда после Майского переворота 1926 г. ведущие посты в воеводстве заняли люди, прибывшие извне, они не воспользовались поддержкой ни одной из влиятельных местных польских общественных групп.

Примерно до 1932 г. административный аппарат воеводства, возглавляемый Г. Юзевским, в соответствии с концепцией «сокальского кордона», суть которой заключалась в отделении Волыни от политического влияния «галицкого украинизма», все усилия направил на ликвидацию тех украинских организаций, центр которых находился в Восточной Галиции. Украинское национальное движение этого региона, руководство которого рассматривало Волынь как важнейшее направление своей идейно-политической и культурной экспансии, воевода считал величайшей опасностью для политики «польско-украинского сближения» на Волыни ${ }^{44}$. В сентябре 1931 г. он разработал секрет-

\footnotetext{
${ }^{42}$ Давидюк Р. Еміграція УНР на Волині в умовах першої радянізації (вересень 1939 - червень 1941 рр.) // «З архівів ВУЧК-ГПУ-НКВДКГБ». № 2 (33) 2009. С. 357.

${ }^{43}$ Аграрной колонизацией, ликвидацией сервитутов.

${ }^{44}$ Социально-политические предпосылки для такого взгляда имелись. По уровню развития национального самосознания украинцев, в частности, степени их политической активности, Волынь заметно отличались от Восточной Галиции, поскольку эти два региона в течение около полутора сотен лет развивались в совершенно разных социально-политических условиях. Политическая активность галицких украинцев опережала все прочие населенные этим народом территории, причем польские власти никогда не ставили здесь практическую задачу национальной ассимиляции местного украинского населения с польским. Сами же украинские национальные организации Восточной Малопольши (Офици-
} 
ный документ, который подал министру внутренних дел Польши. В нем, помимо прочего, содержались конкретные предложения по тактике постепенного отграничения всех восточных и северо-восточных земель страны от галицких воеводств по линии «сокальского кордона». «Нынешняя политическая ситуация на Волыни, - отмечал Г. Юзевский, - учитывая соседство с Восточной Малопольшей, обязывает совершить определенные шаги, которые, с одной стороны, предотвратили бы распространение террористических выступлений, а с другой - подчеркнули бы политическую обособленность Волыни» ${ }^{45}$. В этих целях власти воеводства запретили деятельность базировавшихся по ту - галицкую - сторону «сокальского кордона» культурно-образовательных (общества «Просвита», «Ридна школа» и др.), общественных (Союз Украинок), военизированных («Сич», «Луг», «Сокол» и др.), экономических (украинская кооперация) учреждений и организаций, которые непрерывно боролись со всеми политическими партиями, действовавшими в регионе. Также была закрыта мощная прокоммунистическая организация «Сель-Роб» ${ }^{46}$ : к 1932 г. в воеводстве действовала 341 её ячейка, насчитывавший свыше 10 тыс. чел. ${ }^{47}$ Возникший в результате запрета многих украинских политических и иных организаций, базировавшихся в Восточной Галиции, вакуум должны были заполнить новые, подконтрольные власти, организации смешанного польско-украинского характера.

Репрессии польской администрации воеводства, осуществленные по отношению к украинским оппозиционным партиям, значительно ослабили их позиции уже на парламентских выборах 1930 г., полную победу на которых одержала региональная группа Беспартийного блока сотрудничества с правительством (BBWR), который возглавлялся В. Славеко. В региональную группу вошли представители всех проправительственных организаций и партий от всех регионов Второй Речи Посполитой, в том числе и те, которые представляли национальные меньшинства. В Блок вошла группа украинских деятелей-предста-

альное польское название Восточной Галиции) рассматривали Волынь как важнейшее направление своей идейно-политической и культурной экспансии, для успеха которой имелись основания. Этого и стремился не допустить Г. Юзевский.

${ }^{45}$ Калішук O. До проблеми сокальського кордону (за матеріалами міжвоєнної преси) // Україна: культурна спадщина, національна свідомість, державність: 3б. наук. праць. Львів, 2012. Вип. 21. C. 356 .

46 Українське Селянсько-Робітниче Соціалістичне Об'єднання.

${ }^{47}$ Kessik J. Zaufany Komendanta... S. 142. вителей УНР-овской эмиграции на Волыни, которая пользовалась поддержкой воеводы. Он отмечал: «Региональная группа «беспартийный блок» <...> есть реальный символ государственной политики на Волыни, который вырабатывает основы совместной работы, совместных прав и обязанностей перед государством, <..> является символом здоровой государственно-политической тенденции...» ${ }^{48}$.

Важным событием в рамках реализации программы «государственной ассимиляции» украинцев на Волыни было появление в 1931 г. Волынского Украинского Объединения (ВУО) - новой украинской политической организации пропольской ориентации. Оно было учреждено украинскими послами в Сейме от Волынского воеводства, входящими в состав BBWR 49 по инициативе Г. Юзевского и находилось в полной зависимости от него.

По замыслу воеводы, партия должна была объединить вокруг себя представителей всех проправительственных сил Волыни, получить одобрение и поддержку со стороны наибольшего количества украинского населения Волынского воеводства, при этом действовать под опекой местной администрации, реализуя собственную политическую концепцию. Г. Юзевский рассматривал ВУО как идейную руководящую силу для волынских украинцев, которая стало бы формой проявления их национально-общественного самосознания. Главную задачу партии он видел в создании политического аппарата, который дал бы возможность польской администрации взять под свой контроль настроения широких слоев украинского крестьянства. Осуществить это предполагалось с помощью общественных организаций, связанных с ВУО и стоявших на платформе польско-украинского сотрудничества.

Во главе партии стояли бывшие петлюровцы и гетманцы ${ }^{50}$, руководителем её до июня 1936 г. являлся Д. Певний, затем - С. Тимошенко. Состав ВУО в 1933 - 1934 гг. возрос с 818 до 1591 чел., а в 1937 г. достиг 4800 членов ${ }^{51}$. Наибольшим влиянием партия пользовалась в средней Волыни - восточных поветах воеводства. Советские аналитики партийно-полити-

\footnotetext{
${ }^{48}$ Цит. по: Крамар Ю. Участь українських політичних партій ... // Наук. вісн. Волин. нац. ун-ту ім. Лесі Українки. Рівне, 2007. Вип. 1: Іст. науки. С. 201.

49 Образовывавшими упомянутую выше Украинскую парламентскую репрезентацию Волыни - УПРВ.

${ }^{50}$ Соратники гетмана П. Скоропадского.

51 Ярош Б. О. Трансформаційні політичні процеси на Волині в міжвоєнний період (1921-1939 рр.) // Наук. вісн. Волин. нац. ун-ту ім. Лесі Українки. Луцьк, 2007. Вип. 1: Іст. науки. С. 258.
} 
DOI: $10.7256 / 1811-9018.2014 .6 .12032$

При цитировании этой статьи сноска на доі обязательна

\section{Право и политика $6(174) \cdot 2014$}

ческих сил межвоенной Польши утверждали: «...ВУО объединяет элементы... кулаков на Волыни, наиболее тесно связанные с низовым государственным аппаратом (сельские старосты и волостные старшины)... $)^{52}$.

До недавнего времени ВУО считалось преимущественно деструктивной силой в украинской политической жизни межвоенного периода, однако, комплексное исследование истории Объединения, впервые предпринятое в украинской историографии М. Кучерепой и Р. Давидюк ${ }^{53}$, показало его конструктивную роль как политической платформы политики Г. Юзевского. В своей программе ВУО декларировало, что стоит на идее федерализма, тогда как проблемы национальных меньшинств могут быть решены парламентом и правительством Второй Речи Посполитой, а так называемый «сокальский кордон» является естественной границей, разделяющий два отдельных украинских организма. При этом, господствующий в Галичине национализм является одинаково вредным для украинцев, как и коммунизм, созданная же партия является единственным представителем украинского населения Волыни перед Польским Правительством ${ }^{54}$. Лидеры и члены ВУО стремились сплотить в своих рядах все сословия - крестьян, духовенство, мещан, рабочих, интеллигенцию ${ }^{55}$.

Политическая доктрина Г. Юзевского предполагала формирование мощной социальной базы для развития политического процесса в регионе в будущем. Поэтому воевода сделал ставку на украинское молодежное движение в регионе: он старался всячески поддержать смешанный по национальному составу (польско-украинский) Волынский союз сельской молодежи (ВССМ). Начало этого союза восходят еще к 1918-1919 гг., а в 1927 г. он насчитывал 1700 членов, из них 400 украинцев ${ }^{56}$. Благодаря государственной под-

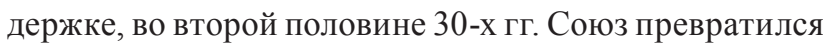
в самую многочисленную общественно-политическую

\footnotetext{
52 Политические партии в Польше, Западной Белоруссии и Западной Украине / Под ред. С. Скульского. Минск, 1935. С. 332-333.

${ }_{53}$ Кучерепа М. М., Давидюк Р. П. ВУО. Волинське українське об’єднання (1931-1939 рр.). Луцьк, 2001.

${ }^{54}$ Калішук О. До проблеми сокальського кордону... // Україна: культурна спадщина, національна свідомість, державність: Зб. наук. праць. Львів, 2012. Вип. 21. С. 257.

${ }^{55}$ Кучерепа М. М., Давидюк Р. П. ВУО... С. 77.

${ }^{56}$ Mędrzecki W. Województwo Wołyńskie... S. 167. При этом, за период 1927-1930 гг. ВССМ получил 20 тыс. злотых финансовой помощи из бюджета (Mędrzecki W. Inteligencja polska na Wołyniu w okresie międzywojennym. Warszawa, 2005. S. 248).
}

организацию воеводства: в 1937 г. структура ВССМ насчитывала 308 ячеек и около 7500 членов, из которых 1630 поляков и 5712 украинцев ${ }^{57}$.

Важным фактором социально-политической стабилизации в воеводстве Г. Юзевский считал сотрудничество поляков и украинцев в органах местного самоуправления, пусть и достаточно ограниченного по своей функциональности ${ }^{58}$. В 1934 г. Г. Юзевский, давая общий обзор состояния политической, экономической и культурной жизни Волыни, писал: «В настоящее время наиболее реальной и решающей основой для формирования украинско-польских отношений является самоуправление. Этот метод (самоуправление) - не единичная политическая акция. Желанием правительства есть и всегда будет не только поддержание нынешнего положения вещей, но и, с течением времени, создание все большей гарантии аполитичности территориального самоуправления, а также гарантий совместного, искреннего, конкретного польско-украинского сотрудничества ${ }^{59}$. Приведенные слова определяют роль и место самоуправления не только в формировании государственно-административной системы Второй Речи Посполитой, но и в решении политических вопросов в центре и, главное, на местах - так, как это видело руководство воеводства.

Из 14 членов Воеводского совета ${ }^{60}$, избранных на основе общего представительства от разных национальностей в 1934 г., 7 были поляками и 7 - украинцами, при этом, из последних все являлись членами проправительственной партии ВУО, полностью разделяли идеи «волынского эксперимента». На выборах в городские органы самоуправления 1934 г. представители проправительственного BBWR получили 202 мандата, еще 72 - представители еврейских пар-

\footnotetext{
${ }^{57}$ KęsikJ. Województwo Wołyńskie 1921-1939 w świetle liczb i faktów // Przegląd Wschodni. 1997. T.4. Z.1(13). S. 134. Впрочем, ВССМ ограничил свою деятельность культурно-просветительскими мероприятиями и не смог нейтрализовать влияние на молодежь нелегальных ОУН и КПЗУ.

${ }^{58}$ Органы самоуправления не были самостоятельными при выполнении многих поставленных перед ними задач. Целый ряд законов, правительственных предписаний, распоряжений ограничивал их независимость в кадровых вопросах, налоговой политике, предпринимательской деятельности и т. п. (См.: Мартинюк Я. М. Органи міського і територіального самоврядування на Волині (1919-1939 рр.) // Наук. вісн. Волин. нац. ун-ту ім. Лесі Українки. Луцьк, 2007. Вип. 1: Іст. науки. С. 204 - 211).

${ }^{59}$ Цит. по: Ющук В. Л. Становлення і функціонування державноадміністративних та самоврядних органів влади на Любомльщині в міжвоєнний період // Наук. вісн. Волин. нац. ун-ту ім. Лесі Українки. Луцьк, 2009. Вип. 22: Іст. науки. С. 309.

${ }^{60}$ Являлся высшим представительным органом на уровне воеводств.
} 
тий ${ }^{61}$. Вместе с тем, воевода обязывал государственных и самоуправляющихся чиновников употреблять украинский язык в контактах с украинскими жителями подведомственного региона ${ }^{62}$.

Однако, хотя органы МСУ и представляли собой организации со смешанным национальным составом, ведущим в них был польский элемент. Кроме того, анализируя соотношение поляков и украинцев в местных органах власти, становится заметно, что представительство последних в органах самоуправления всех уровней лишь уменьшалось. Так, если сравнить результаты выборов в органы самоуправления 1930 и 1934 гг., то можно увидеть рост доли поляков в этих структурах на территории Волынского воеводства на 17,08\% при снижении доли украинцев на $13,56 \%{ }^{63}$. Уменьшалась доля украинцев в советах сельских гмин: если в 1932 г. поляки составляли 23,5\%, украинцы-67,1\%, то в 1937 г. доля поляков возросла до $38,69 \%$, а украинцев снизилась до 54,63\% ${ }^{64}$. По данным Я. Цецика, еще в начале 1934 г. среди работников органов всех 103 гминных управлений воеводства числилось 67,1\% украинцев, $25,4 \%$ поляков, $6,1 \%$ русских, что превышало количество представителей восточнославянских меньшинств в органах местного самоуправления других воеводств «восточных кресов». Однако, данная тенденция не оказалась долговременной: уже 1 июля 1935 г. поляков там было 40,3\%, а украинцев - 53,1\% ${ }^{65}$.

Как один из методов реализации «волынской программы» можно отметить реорганизацию кооперативного движения на Волыни, которое должно было стать, по сути, основой гражданского общества для волынских украинцев, учитывая преобладание среди них аграрного населения. При этом, воевода считал распространенные в регионе кооперативы Ревизионного союза украинских кооперативов в Львове (РСУК) олицетворением «агрессивного галицкого национализма». С целью реализации принципов смешанной польско-украинской кооперации в конце 1933 г. по

\footnotetext{
${ }^{61}$ Drugi powszechny spis ludności z dnia 7 grudnia 1931 r. Mieszkania i gospodarstwa domowe. Ludnośc. Stosunki zawodowe. Województwo Wołyńskie. T.70. Warszawa, 1938. S. 88.

${ }^{62}$ Mędrzecki $W$. Inteligencja polska... S. 195.

63 Давидюк Р. П. Українсько-польські організації ... // Актуальні проблеми вітчизняної та всесвітньої історії: Зб. наук. праць. Наук. зап. Рівненського держ. гум. ун-ту. Рівне, 2009. Вип. 17. Эл. версия: http://archive.nbuv.gov.ua/portal/soc_gum/apvvi/2009_17/ davyduk.pdf.

64 Там же.

65 Цеицк Я. П. Польсько-українські взаємовідносини на Волині напередодні Другої світової війни: причини конфронтації // Сторінки історії. К., 2010. Вип. 31. С. 119.
}

инициативе местных властей появились первые очаги кооперативного союза «Гурт» с польско-украинским составом и во главе с Й. Волошиновским. Процесс становления кооперативных предприятий «Гурта» проходил, во многом, путем переподчинения ему последних оставшихся кооперативов РСУК на Волыни. Но, при этом, общий характер функционирования «Гурта» был противоречивым ${ }^{66}$.

Помимо «Гурта», в качестве смешанных польскоукраинских организаций на Волыни создавались многочисленные сельскохозяйственные кружки, кружки сельских хозяек, сельскохозяйственная палата. В целом, в отношении экономической части «волынской программы» успех не заставил себя долго ждать. Так, численность украинских кооперативов только за 1930 - 1933 гг. увеличилась с 295 до $787^{67}$, хотя их реальные экономические достижения нельзя назвать блестящими ${ }^{68}$.

Уже в 1933 г. Г. Юзевский признал, что политическая жизнь волынских украинцев, довольно примитивная в конце 20 -х годов, значительно оживилась, а Волынь представляла собой «поприще особенно интенсивных атак Малопольши - атак за прорыв «сокальского кордона» ${ }^{69}$. Действительно, к тому времени некоторые достижения в реализации

\footnotetext{
${ }^{66}$ Функции главного организатора местных ячеек «Гурта» зачастую выполняли представители местной государственной администрации. Как следствие, быстро росла численность членов кооператива: если в начале своего образования он насчитывал 3900 членов, то через четыре года это число возросло до 23 тыс. чел. С 1934 по июнь 1938 г. было образовано 40 районных организаций и 141 магазин «Группы» (Mędrzecki W. Województwo Wołyńskie... S.167). Однако, экономические результаты работы были значительно хуже, удостоверяющий факт задолженности кооператива в 1936 году, которая составляла около 366 тыс. злотых (Madajczyk Cz. Materiały w sprawie polityki narodowościowey władz polskich po przewrocie majowym // Dzieje Najnowsze. 1972. Z.3. S. 154).

${ }^{67}$ Kęsik J. «Kordon sokalski». Problemy pogranicza galicyjskowołyńskiego w latach 1921-1939 // Studia z dziejów prowincji galicyjskiej / pod red. Adama Galosa. Wrocław, 1993. S 141 - 142.

68 Численность легальных украинских организаций существенно уступала численности польских. Так, в 1936 г. около 30 тыс. поляков, проживавших в Волынском воеводстве, являлись членами своих национальных союзов и обществ (Крамар Ю. В. Роль польських громадсько-політичних організацій Волині у реалізації політики воєводи Г. Юзевського // Наук. вісн. Волин. нац. ун-ту ім. Лесі Українки. Луцьк, 2010. Вип. 10: Іст. науки. С. 48), крупнейшими из которых были «Союз польских харцеров», «Стрелецкий союз», «Союз военных осадников», «Союз воленных инвалидов». Следует отметить, что в эти организации можно было вступать и украинцам.

${ }^{69}$ Калішук О. До проблеми сокальського кордону... // Україна: культурна спадщина, національна свідомість, державність: Зб. наук. праць. Львів, 2012. Вип. 21. С. 359.
} 
DOI: $10.7256 / 1811-9018.2014 .6 .12032$

При цитировании этой статьи сноска на ооі обязательна

\section{Право и политика $6(174) \cdot 2014$}

«волынской программы» воеводы имели место. Так, доля украинцев среди работников органов гминных правлений воеводства на какое-то время превысила число представителей восточнославянских меньшинств в местных органах управления других воеводств «восточных кресов». Удалось свести к минимуму деятельность галицких украинских организаций на территории Волынского воеводства и переподчинить волынские кооперативы вместо Львова Варшаве, а также резко ограничить политическое влияние со стороны восточно-галицкого украинского движения. А ОУН начала практиковать теракты в регионе только во второй половине 1930-х гг. ${ }^{70}$, но, впрочем, вскоре вернулась к тактике политических акций и пропагандистской работы. Таким образом, предотвратить радикализацию украинского национального движения и политического процесса в целом на подведомственной ему территории Г. Юзевскому удалось. Во многом, помимо перечисленных выше мер, это произошло благодаря тому, что он поддержал активизировавшееся примерно с 1933 г. движение за украинизацию православной церкви, которая рассматривалась воеводской администрацией как важный инструмент ассимиляционной политики. Воевода рассматривал православие как важный элемент обособленности Волыни от Восточной Галичины ${ }^{71}$. При этом, украинизация православной церкви аккумулировала на себе значительную долю общественной активности украинцев, привлекла внимание и деятельное участие немалого числа украинских активистов. Ввиду низкого уровня национального сознания украинского крестьянства Волыни, принадлежность к православной церкви была для многих из них едва ли не единственным признаком национальной идентичности, способствовала её укреплению и развитию политического сознания в конструктивном направлении.

\footnotetext{
70 Ленартович О. Формування організаційної структури та діяльність українського націоналістичного підпілля на Волині у 1930-х рр. // Проблеми історії України: факти, судження, пошуки: Міжвід. зб. наук. пр. 2010. Вип. 19(2). С. 174. В 1935 г. на Волыни были образованы две региональные ячейки ОУН, а в 1937 г., при действенном участии В. Сидора, начали формироваться повстанческо-боевые отделы ОУН, готовившие в т. ч. покушения на Г. Юзевского. Этот процесс не удалось завершить из-за проведенных полицией в 1937 г. арестов членов организации (Цецик Я. П. Діяльність українських національних партій на Волині у міжвоєнний період: автореф. дис. ... канд. іст. наук. Чернівці, 2008. С. 15).

${ }^{71}$ Материалы, освещающие процесс украинизации православной церкви на Волыни, хранятся в фонде 63 ДАВО («Управа товариства прихильників православної освіти та охорони традицій православної віри імені Петра Могили»).
}

В то же время, политический процесс в Волынском воеводстве оставался, в значительной степени, под контролем польской стороны. Юридическая и фактическая социально-политическая асимметрия между поляками и украинцами практически не сокращалась. При этом, следует помнить, что в иных воеводствах «восточных кресов» условия, в которых находилось восточнославянское население, были значительно более суровыми, характер же политического процесса в начале 1930-х гг. претерпел заметную трансформацию в сторону авторитаризации. Поэтому, промежуточные результаты воздействия политики Г. Юзевского на политический процесс в Волынском воеводстве можно сколь-нибудь объективно оценить лишь в контексте тенденций общегосударственного масштаба.

Смерть 12 мая 1935 г. Ю. Пилсудского, главного протектора «волынского эксперимента», и изменение характера политической системы Польши после принятия 23 апреля 1935 г. новой Конституции, зафиксировавшей тенденцию к нарастанию авторитаризма, выразившегося, в том числе, в переходе к политике национальной ассимиляции меньшинств на всей территории «восточных кресов», стимулировали регресс и в осуществлении «эксперимента». По итогам выборов в Сейм и Сенат, состоявшихся по новой схеме ${ }^{72}$ в сентябре 1935 г., волынские украинцы были представлены в польском парламенте 6 депутатами, из них 5 - от ВУО.

Под влиянием общегосударственных тенденций во Второй Речи Посполитой, уже в середине 1930-х гг. стало очевидным, что «волынский эксперимент» в том виде, как он задумывался и, в значительной степени, в своей политической составляющей, терпит крах. Во-первых, насаждаемые сверху украинско-польские учреждения не пустили прочных корней. Во-вторых, социальная ситуация в воеводстве имела тенденцию к обострению. Наконец, в-третьих, программа Г. Юзевского имела весьма узкую базу сторонников в польских правящих кругах и, тем более, военной среде, представители которой уже в течение продолжительного времени определяли направление польской правительственной политики в ряде ключевых вопросов, имея серьезное влияние также и на этническую политику.

Помимо этих факторов, в качестве одной из главных причин неудачи в развитии «волынской программы»

\footnotetext{
${ }^{72}$ В Сейме IV созыва, в 1935-1937 гг., после ликвидации посольских клубов, был принят принцип разделения его участников по территориальному принципу. Послы и сенаторы сформировали региональные воеводские группы. Но из этой схемы выпали послы национальных меньшинств: группа украинских послов из Восточной Галиции, украинская группа из Волыни (была также Еврейская группа). В 1937 г. фактически единственной фракцией Сейма стал Фронт Народного Единства.
} 
DOI: $10.7256 / 1811-9018.2014 .6 .12032$

При цитировании этой статьи сноска на dоі обязательна

История государства и права

можно выделить негативную позицию местных поляков относительно политики Г. Юзевского ${ }^{73}$, который справедливо отмечал, что «польское сознание, не способное к проявлению симпатии и доброжелательности к украинскому обществу, когда оно обнаруживает приверженность государству, есть государственная катастрофа $>^{74}$. Консолидация молодой генерации волынских украинцев на основе идеологии интегрального национализма лишь укрепляла среди поляков чувство страха перед угрозой «украинской экспансии», способствовала росту уже польского национализма среди польской общественности, бюрократии, католического духовенства и военных. Именно поэтому подавляющее большинство польского населения воеводства, и без того более чем настороженно относившееся к поведению украинского населения и связанными с ним процессами, ко второй половине 1930-х гг. оказалось настроено враждебно к любым начинаниям воеводы относительно польскоукраинского сближения.

В силу этих факторов политику Г. Юзевского стали массово бойкотировать на местах. После же ликвидации воеводой большинства легальных, выступавших за независимость, украинских организаций, имевших, в отличие от ВУО, четко оформленную социальную базу, узость таковой у «волынского эксперимента» способствовала развитию тенденции к укреплению на территории воеводства позиций нелегального украинского коммунистического и националистического движений, представленных, прежде всего, ОУН и КПЗБ.

Существенной стороной политической деятельности Г. Юзевского в период 1935-1938 гг. были его все более натянутые отношения с высшим военным руководством страны, а в 1937 г. он фактически утратил контроль над развитием событий в отношении украинского населения региона ${ }^{75}$. В 1937-1938 гг.,

\footnotetext{
${ }^{73}$ Как писал воевода в отчете за 1936 г., «можно решиться утверждать, что во многих случаях польское общество тормозит государственную ассимиляцию украинского населения своим неприязненным отношением к этому населению, даже если с украинской стороны встречаются проявления доброжелательного отношения к Польше» (цит. по: Сивіцький М. Історія польськоукраїнських конфліктів. Т. 1// Эл. версия: http://uadocs.exdat.com/ docs/index-170605.html?page=13).

${ }^{74}$ Цит. по: Сивіщький М. Історія польсько-українських конфліктів. Т. 1// Эл. версия: http://uadocs.exdat.com/docs/index-170605. html?page $=13$

${ }^{75}$ В том году в Варшаве был провозглашен курс на «ревиндикацию» - «возвращение» православного населения «восточных кресов» в католицизм. За этим последовало столь жесткое наступление на восточнославянские меньшинства Второй Речи Посполитой, что вести речь о каком-либо легальном политическом процессе повсюду, за исключением Восточной Галиции, уже не приходилось. См.:
}

польское правительство, реализуя программу укрепления польского присутствия на восточных территориях Речи Посполитой, приступило к открытой принудительной ассимиляции украинского населения, что было совершенно несовместимо с курсом волынского воеводы. Эти факторы стали решающими причинами отставки Г. Юзевского в апреле 1938 года. Уже после перевода воеводы в Лодзь недоброжелательный к нему «Kurier Wołyński» написал, что пришел конец «десятилетнему мученичеству» польской общественности Волыни ${ }^{76}$.

Таким образом, «Волынская программа» Г. Юзевского представляла собой наиболее яркую и комплексную попытку создания модели двустороннего польскоукраинского сотрудничества в период существования Второй Речи Посполитой на региональном уровне. Волынское воеводство было выбрано для этого не случайно: наличие объективных условий для запуска анализируемой социально-политической программы проявлялось в таких аспектах, как отсутствие на территории региона очагов радикального национализма как с польской, так и с украинской сторон, равно как и сложившихся центров развития, наряду со значительным демографическим и социокультурным потенциалом, формировали подходящие условия для создания именно здесь комплексных программ развития.

«Волынская программа» была разработана на основе тщательного анализа ситуации в воеводстве, с использованием выработанных ранее в стране идейно-концептуальных подходов к тематике, посвященной политике польских властей в отношении восточнославянских национальных меньшинств. Однако, по причине резкого контраста между исходными факторами и условиями, с одной стороны, и реальной ситуации, обусловленной курсом польских властей, особенно во второй половине 1930-х гг,, «волынский эксперимент», начавший осуществляться в Волынском воеводстве на основе «волынской программы», зашел в тупик и был сменен, после отстранения воеводы Г. Юзевского, программой полной национальной ассимиляции восточнославянского населения региона, полномасштабной реализации которой помешало лишь прекращение существования Второй Речи Посполитой в сентябре 1939 г.

Гудь Б. Політика «ревіндикації» на Холмщині і Волині 1937-1938 pp. та ії наслідки для українсько-польських стосунків // Україна: культурна спадщина, національна свідомість, державність. Львів, 2012. Вип. 21. С. 258.

76 Данилюк В. Забутий воєвода // Волинська газета. Вип. от 25.04.2013. // Эл. версия: http://volga.lutsk.ua/view/487/2/ 


\section{Право и политика $6(174) \cdot 2014$}

\section{Библиография:}

1. Боротьба трудящих Волині за визволення з-під гніту панської Польщі і возз'єднання з радянською Україною: збірник документів і матеріалів. Частина II (1929 - 1939 рр.). Львів, 1965.

2. Генрик Юзевський. Замість щоденника // «Роде наш красний...» Волинь у долях краян і людських документах. Т. 2. Луцьк, 1996.

3. Гнатюк О. Між літературою і політикою. Есеї та інтермедії. К., 2012.

4. Гудь Б. Політика «ревіндикації» на Холмщині і Волині 1937-1938 pр. та ії наслідки для українськопольських стосунків // Україна: культурна спадщина, національна свідомість, державність. Львів, 2012. Вип. 21. С. $256-266$.

5. Давидюк Р. Еміграція УНР на Волині в умовах першої радянізації (вересень 1939 - червень 1941 pp.) // «3 архівів ВУЧК-ГПУ-НКВД-КГБ». № 2 (33) 2009. С. $353-369$.

6. Давидюк Р. П. Політичні процесі Західної Волині міжвоєнного періоду в сучасній українській історіографії // Слов'янський вісник. Збірник наукових праць. Рівне, 2010. Вип. 10. С. $51-57$.

7. Давидюк Р. Українсько-польські організації як прояв міграцйної політики влади на Волині у міжвоєнний перод // Актуальні проблеми вітчизняної та всесвітньої історії: Зб. наук. праць. Наук. зап. Рівненського держ. гум. ун-ту. Рівне, 2009. Вип. 17. Эл. версия: http://archive.nbuv.gov.ua/ portal/soc_gum/apvvi/2009_17/davyduk.pdf

8. Каліщук О. До проблеми сокальського кордону (за матеріалами міжвоєнної преси) // Україна: культурна спадщина, національна свідомість, державність: Зб. наук. праць. Львів, 2012. Вип. 21. С. 354 - 360.

9. Категории политической науки / Авт. концепции и рук. авт. кол. А. Ю. Мельвиль. М., 2002.

10. Крамар Ю. В. Роль польських громадськополітичних організацій Волині у реалізації політики воєводи Г. Юзевського // Наук. вісн. Волин. нац. ун-ту ім. Лесі Українки. Луцьк, 2010. Вип. 10: Іст. науки.

11. Крамар Ю. В. Участь українських політичних сил Волині, Холмщини та Підляшшя у парламентських виборах 1922 р. // Наук. вісн. Волин. нац. ун-ту ім. Лесі Українки. Луцьк, 2009. Вип. 13: Іст. науки. С. $198-204$.

12. Кугутяк М. В. Історія української націоналдемократії (1918-1929). Т. 1. К.; Івано-Франківськ, 2002.
13. Кучерепа М. М., Давидюк Р. П. ВУО. Волинське українське об'єднання (1931-1939рр.). Луцьк, 2001.

14. Ленартович О. Формування організаційної структури та діяльність українського націоналістичного підпілля на Волині у 1930-х pр. // Проблеми історії України: факти, судження, пошуки: Міжвід. зб. наук. пр. 2010. Вип. 19(2). С. 169 - 177.

15. Мартинюк Я. М. Органи міського і територіального самоврядування на Волині (1919-1939 рр.) // Наук. вісн. Волин. нац. ун-ту ім. Лесі Українки. Луцьк, 2007. Вип. 1: Іст. науки. С. $204-211$.

16. Панасюк В. «Волинська політика» воєвод Г. Юзевського та А. Гавке-Новака 1928 - 1939 років: проблеми україно-та німецькомовної освіти // «Етнічна історія народів Європи». Збірник наукових праць. К., 2004. Вип. 16. С. 126 - 131.

17. Политические партии в Польше, Западной Белоруссии и Западной Украине / Под ред. С. Скульского. Минск, 1935.

18. Сивіцький М. Історія польсько-українських конфліктів. Т. 1// Эл. версия: http://uadocs.exdat. $\mathrm{com} / \mathrm{docs} /$ index-170605.html?page $=13$

19. Цецик Я. П. Вплив Українського національнодемократичного об'єднання на суспільнополітичне життя Волині напередодні Другої світової війни // Науковий вісник: Одеський національний економічний університет. Науки: економіка, політологія, історія. Одеса, 2012. № 2. С. $144-156$.

20. Цецик Я. П. Діяльність українських національних партій на Волині у міжвоєнний період: автореф. дис. ... канд. іст. наук. Чернівці, 2008.

21. Цецик Я. П. Польсько-українські взаємовідносини на Волині напередодні Другої світової війни: причини конфронтації // Сторінки історії. К., 2010. Вип. 31. C. $116-125$.

22. Шваб А. Г. Соціально-економічні процеси на Волині у міжвоєнний період // Волин. Нац. ун-т ім. Лесі Українки. 3б. навч. - методич. Мат-лів і наук. статей Іст. фак-ту. Луцьк, 2008. Вип. 14.

23. Шутов А. Ю. Политический процесс. М., 1994.

24. Ющук В. Л. Становлення і функціонування державно-адміністративних та самоврядних органів влади на Любомльщині в міжвоєнний період // Наук. вісн. Волин. нац. ун-ту ім. Лесі Українки. Луцьк, 2009. Вип. 22: Іст. науки.

25. Ярош Б. О. Трансформаційні політичні процеси на Волині в міжвоєнний період (1921-1939рр.) // Наук. вісн. Волин. нац. ун-ту ім. Лесі Українки. Луцьк, 2007. Вип. 1: Іст. науки. С. $254-259$. 
DOI: $10.7256 / 1811-9018.2014 .6 .12032$

При цитировании этой статьи сноска на doi обязательна

История государства и права

26. Drugi powszechny spis ludności z dnia 7 grudnia 1931 r. Mieszkania i gospodarstwa domowe. Ludnośc. Stosunki zawodowe. Województwo Wołyńskie. T.70. Warszawa, 1938.

27. Kęsik J. «Kordon sokalski». Problemy pogranicza galicyjsko-wołyńskiego w latach 1921-1939 // Studia z dziejów prowincji galicyjskiej / pod red. Adama Galosa. Wrocław, 1993. S. $125-155$.

28. Kęsik J. Województwo Wołyńskie 1921-1939 w świetle liczb i faktów // Przegląd Wschodni. 1997. T.4. Z.1(13). S. $99-137$.

29. Medrzecki W. Województwo Wołyńskie 1921-1939: elementy przemian cywilizacjnych, społecznych I politycznych. Wrocław; Kraków, 1988.

30. Sawicka J. Złota wołyńska struna. O Łobodowskim w tygodniku «Wołyń» // Kresy. 1991. Nr. 16. S. 54 - 59.

31. Madajczyk Cz. Materiały w sprawie polityki narodowościowej władz polskich po przewrocie majowym // Dzieje Najnowsze. 1972. Z.3. S. 143 - 147.

32. Mędrzecki W. Inteligencja polska na Wołyniu w okresie międzywojennym. Warszawa, 2005.

33. Толстокорова А.В. Роль пространственной эмансипации в формировании гендерной идентичности украинских образованных женщин (конец XIXначало XX вв.) // NB: Культуры и искусства. - 2013. - № 1. - C.92-146. DOI: 10.7256/2306-1618.2013.1.316. URL: http://e-notabene.ru/ca/article_316.html

34. Бондарчук И.В. Легализация общественных организаций и политических партий в механизме защиты конституционного строя Украины // NB: Вопросы права и политики. - 2013. - № 6. - С.135151. DOI: $10.7256 / 2305-9699.2013 .6 .6292$. URL: http://e-notabene.ru/lr/article_6292.html

35. Д. А. Боровков. «Се же поручаю в собе мъсто столь старьишему сыну моему и брату вашему...»: традиция и новации в «ряде» Ярослава Мудрого // Исторический журнал: научные исследования. - 2012. - № 6. - С. 58-66.

36. Полтораков А.Ю.. Украинские национальные ценности в геокультурном (цивилизационном) контексте // Философия и культура. - 2013. - № 12 . - C. 1741-1746. DOI: 10.7256/1999-2793.2013.12.7350.

37. Е.В. Бондаренко. Основные субъекты политических отношений в Восточной Галиции в условиях подъема украинского легального политического движения в конце 1920-начале 1930-х гг // Политика и Общество. - 2013. - № 2. - C. 158-167. DOI: $10.7256 / 1812-8696.2013 .02 .5$

38. Е. А. Косован. Организации украинской общины в Германии в межвоенный период: первая волна эмиграции (1915-1939 гг.) // Политика и Общество. - 2012. - № 9. - С. 41-51.

39. А. В. Толстокорова. Пространственная эмансипация украинских женщин как способ освоения публичного пространства // Культура и искусство. - 2012. - № 5. - C. 46-58.

40. Е. А. Косован. Вторая волна иммиграции украинцев в Германию (1945-1953 гг.): история, причины, последствия // Политика и Общество. - 2012. № 4. - C. 82-89.

\section{References (transliteration):}

1. Genrik Yuzevs'kii. Zamist' shchodennika // «Rode nash krasnii...» Volin' u dolyakh krayan i lyuds'kikh dokumentakh. T. 2. Luts'k, 1996.

2. Gnatyuk O. Mizh literaturoyu i politikoyu. Eseï ta intermedii. K., 2012.

3. Gud' B. Politika «revindikatsiï» na Kholmshchini i Volini 1937-1938 rr. ta iï naslidki dlya ukraïns'kopol's'kikh stosunkiv // Ukraïna: kul'turna spadshchina, natsional'na svidomist', derzhavnist'. L'viv, 2012. Vip. 21. S. $256-266$.

4. Davidyuk R. Emigratsiya UNR na Volini v umovakh pershoï radyanizatsiï (veresen' 1939 - cherven' 1941 rr.) // «Z arkhiviv VUChK-GPU-NKVDKGB». № 2 (33) 2009. S. 353 - 369.

5. Davidyuk R. P. Politichni protsesi Zakhidnoï Volini mizhvo€nnogo periodu v suchasnii ukraïns'kii istoriografiï // Slov'yans'kii visnik. Zbirnik naukovikh prats'. Rivne, 2010. Vip. 10. S. $51-57$.

6. Davidyuk R. Ukraïns'ko-pol's'ki organizatsiï yak proyav migratsinoï politiki vladi na Volini u mizhvoennii perod // Aktual'ni problemi vitchiznyanoï ta vsesvitn'oï istoriï: Zb. nauk. prats'. Nauk. zap. Rivnens'kogo derzh. gum. un-tu. Rivne, 2009. Vip. 17. El. versiya: http:// archive.nbuv.gov.ua/portal/soc_gum/apvvi/2009_17/ davyduk.pdf

7. Kalishchuk O. Do problemi sokal's'kogo kordonu (za materialami mizhvoennoï presi) // Ukraïna: kul'turna spadshchina, natsional'na svidomist', derzhavnist': Zb. nauk. prats'. L'viv, 2012. Vip. 21. S. $354-360$.

8. Kramar Yu. V. Rol' pol's'kikh gromads'kopolitichnikh organizatsii Volini u realizatsiï politiki vo€vodi G. Yuzevs'kogo // Nauk. visn. Volin. nats. untu im. Lesi Ukraïnki. Luts'k, 2010. Vip. 10: Ist. nauki.

9. Kramar Yu. V. Uchast' ukraïns'kikh politichnikh sil Volini, Kholmshchini ta Pidlyashshya u parlaments'kikh viborakh 1922 r. // Nauk. visn. Volin. 


\section{Право и политика $6(174) \cdot 2014$}

nats. un-tu im. Lesi Ukraïnki. Luts'k, 2009. Vip. 13: Ist. nauki. S. $198-204$.

10. Kugutyak M. V. Istoriya ukraïns'koï natsionaldemokratiï (1918-1929). T. 1. K.; Ivano-Frankivs'k, 2002.

11. Kucherepa M. M., Davidyuk R. P. VUO. Volins'ke ukraïns'ke ob'€dnannya (1931-1939 rr.). Luts'k, 2001.

12. Lenartovich O. Formuvannya organizatsiinoï strukturi ta diyal'nist' ukraïns'kogo natsionalistichnogo pidpillya na Volini u 1930-kh rr. // Problemi istorii Ukraïni: fakti, sudzhennya, poshuki: Mizhvid. zb. nauk. pr. 2010. Vip. 19(2). S. 169 - 177.

13. Martinyuk Ya. M. Organi mis'kogo i teritorial'nogo samovryaduvannya na Volini (1919-1939 rr.) // Nauk. visn. Volin. nats. un-tu im. Lesi Ukraïnki. Luts'k, 2007. Vip. 1: Ist. nauki. S. $204-211$.

14. Panasyuk V. «Volins'ka politika» vo€vod G. Yuzevs'kogo ta A. Gavke-Novaka 1928 - 1939 rokiv: problemi ukraïno-ta nimets'komovnoï osviti // «Etnichna istoriya narodiv Evropi». Zbirnik naukovikh prats'. K., 2004. Vip. 16. S. 126 - 131.

15. Sivits'kii M. Istoriya pol's'ko-ukraïns'kikh konfliktiv. T. 1// El. versiya: http://uadocs.exdat.com/docs/index-170605.html?page $=13$

16. Tsetsik Ya. P. Vpliv Ukraïns'kogo natsional'nodemokratichnogo ob'€dnannya na suspil'no-politichne zhittya Volini naperedodni Drugoï svitovoï viini // Naukovii visnik: Odes'kii natsional'nii ekonomichnii universitet. - Nauki: ekonomika, politologiya, istoriya. Odesa, 2012. № 2. S. $144-156$.

17. Tsetsik Ya. P. Diyal'nist' ukraïns'kikh natsional'nikh partii na Volini u mizhvoennii period: avtoref. dis. ... kand. ist. nauk. Chernivtsi, 2008.

18. Tsetsik Ya. P. Pol's'ko-ukraïns'ki vza€movidnosini na Volini naperedodni Drugoï svitovoï viini: prichini konfrontatsiï // Storinki istoriï. K., 2010. Vip. 31. S. $116-125$.

19. Shvab A. G. Sotsial'no-ekonomichni protsesi na Volini u mizhvoennii period // Volin. Nats. un-t im. Lesi Ukraïnki. Zb. navch. - metodich. Mat-liv i nauk. statei Ist. fak-tu. Luts'k, 2008. Vip. 14.

20. Shutov A. Yu. Politicheskii protsess. M., 1994.

21. Yushchuk V. L. Stanovlennya i funktsionuvannya derzhavno-administrativnikh ta samovryadnikh organiv vladi na Lyuboml'shchini v mizhvoennii period // Nauk. visn. Volin. nats. un-tu im. Lesi Ukraïnki. Luts'k, 2009. Vip. 22: Ist. nauki.

22. Yarosh B. O. Transformatsiini politichni protsesi na Volini v mizhvoennii period (1921-1939 rr.) // Nauk. visn. Volin. nats. un-tu im. Lesi Ukraïnki. Luts'k, 2007. Vip. 1: Ist. nauki. S. $254-259$.

23. Drugi powszechny spis ludności z dnia 7 grudnia 1931 r. Mieszkania i gospodarstwa domowe. Ludnośc. Stosunki zawodowe. Województwo Wołyńskie. T.70. Warszawa, 1938.

24. Kęsik J. «Kordon sokalski». Problemy pogranicza galicyjsko-wołyńskiego w latach 1921-1939 // Studia z dziejów prowincji galicyjskiej / pod red. Adama Galosa. Wrocław, 1993. S. $125-155$.

25. Kęsik J. Województwo Wołyńskie 1921-1939 w świetle liczb i faktów // Przegląd Wschodni. 1997. T.4. Z.1(13). S. $99-137$.

26. Medrzecki W. Województwo Wołyńskie 1921-1939: elementy przemian cywilizacjnych, społecznych I politycznych. Wrocław; Kraków, 1988.

27. Sawicka J. Złota wołyńska struna. O Łobodowskim w tygodniku «Wołyń» // Kresy. 1991. Nr. 16. S. 54 - 59.

28. Madajczyk Cz. Materiały w sprawie polityki narodowościowej władz polskich po przewrocie majowym // Dzieje Najnowsze. 1972. Z.3. S. 143 - 147.

29. Mędrzecki W. Inteligencja polska na Wołyniu w okresie międzywojennym. Warszawa, 2005.

30. Tolstokorova A.V. Rol' prostranstvennoi emansipatsii v formirovanii gendernoi identichnosti ukrainskikh obrazovannykh zhenshchin (konets XIX-nachalo XX vv.) // NB: Kul'tury i iskusstva. - 2013. - № 1. - S.92-146. DOI: 10.7256/2306-1618.2013.1.316. URL: http://enotabene.ru/ca/article_316.html

31. Bondarchuk I.V. Legalizatsiya obshchestvennykh organizatsii i politicheskikh partii $\mathrm{v}$ mekhanizme zashchity konstitutsionnogo stroya Ukrainy // NB: Voprosy prava i politiki. - 2013. - № 6. - S.135-151. DOI: 10.7256/2305-9699.2013.6.6292. URL: http://enotabene.ru/lr/article_6292.html

32. D. A. Borovkov. «Se zhe poruchayu v sobe mbsto stol" starbishemu synu moemu i bratu vashemu...»: traditsiya i novatsii v «ryade» Yaroslava Mudrogo // Istoricheskii zhurnal: nauchnye issledovaniya. -2012. - № 6. - S. 58-66.

33. Poltorakov A.Yu.. Ukrainskie natsional'nye tsennosti v geokul'turnom (tsivilizatsionnom) kontekste // Filosofiya i kul'tura. - 2013. - № 12. - S. 1741-1746. DOI: 10.7256/1999-2793.2013.12.7350.

34. E.V. Bondarenko. Osnovnye sub"'ekty politicheskikh otnoshenii v Vostochnoi Galitsii v usloviyakh pod"ema ukrainskogo legal'nogo politicheskogo dvizheniya v kontse 1920-nachale 1930-kh gg // Politika i Obshchestvo. - 2013. - № 2. - S. 158-167. DOI: 10.7256/1812-8696.2013.02.5 
DOI: $10.7256 / 1811-9018.2014 .6 .12032$

При цитировании этой статьи сноска на doi обязательна

История государства и права

35. E. A. Kosovan. Organizatsii ukrainskoi obshchiny v Germanii v mezhvoennyi period: pervaya volna emigratsii (1915-1939 gg.) // Politika i Obshchestvo. 2012. - № 9. - S. 41-51.

36. A. V. Tolstokorova. Prostranstvennaya emansipatsiya ukrainskikh zhenshchin kak sposob osvoeniya pub- lichnogo prostranstva // Kul'tura i iskusstvo. - 2012. - № 5. - S. 46-58.

37. E. A. Kosovan. Vtoraya volna immigratsii ukraintsev v Germaniyu (1945-1953 gg.): istoriya, prichiny, posledstviya // Politika i Obshchestvo. - 2012. - № 4. - S. 82-89. 